\title{
Facts and Doubts about the Beginning of Human Life and Personality
}

\author{
${ }^{1}$ Asim Kurjak, ${ }^{2}$ Lara Spalldi Barisic, ${ }^{3}$ Taib Delic, ${ }^{4}$ Selma Porovic, ${ }^{5}$ Milan Stanojevic
}

\begin{abstract}
Scientists have been negligent in failing to translate science into the terms that allow mankind to share their excitement of discovering life before birth. In spite of remarkable scientific development, man's curiosity, and speculations dating back to Hippocrates, life before birth still remains a big secret. Various kinds of intellectuals were involved in trying to offer their contribution to solve the human life puzzle. Their leading idea is that each newborn child will reach its full potential if its development in uterus is not exposed to any adverse influence, providing the best possible environment for the embryo/fetus. Considering the embryo/fetus, we should always keep in mind the amazing aspect of human life where the mother and the embryo/fetus, although linked in the most intimate relationships, are at all times two separate people. Considering the embryo/fetus as the person opened a new set of questions about its personality and human rights. Today, scientific data and hypotheses, philosophical thought, and issues in the humanities have become a necessity in order to deal with ethical, juridical, and social problems arising from man's interference in many aspects and stages of life.
\end{abstract}

Keywords: Fetal life, Personality, Ultrasound diagnosis.

How to cite this article: Kurjak A, Spalldi Barisic L, Delic T, Porovic S, Stanojevic M. Facts and Doubts about the Beginning of Human Life and Personality. Donald School J Ultrasound Obstet Gynecol 2016;10(3):205-213.

Source of support: Nil

Conflict of interest: None

"What a piece of work is a man."

—William Shakespeare, Hamlet

"To those of average curiosity about the wonders of nature, it is likely that two great mysteries have stirred the imagination; and each concerns a birth. Who has not gazed

\footnotetext{
${ }^{1}$ Professor (Emeritus) and President, ${ }^{2-4}$ Director, ${ }^{5} \mathrm{Head}$ and President

${ }^{1}$ Department of Obstetrics and Gynecology, International Academy of Perinatal Medicine, Zagreb, Croatia

${ }^{2}$ Croatian Branch of lan Donald Inter-University School of Medical Ultrasound, Zagreb, Croatia

${ }^{3}$ Polyclinic Sunce, Sarajevo, Bosnia and Herzegovina

${ }^{4}$ Department of Pediatric Dentistry, Public Health Center of the Sarajevo Canton, Sarajevo, Bosnia and Herzegovina

${ }^{5}$ Department of Obstetrics and Gynecology, Medical School University of Zagreb, Sveti Duh Clinical Hospital, World Academy of Perinatal Medicine, Zagreb, Croatia

Corresponding Author: Asim Kurjak, Professor (Emeritus) and President, Department of Obstetrics and Gynecology International Academy of Perinatal Medicine, Zagreb, Croatia e-mail: asim.kurjak@public.carnet.hr
}

into the heavens on the starlit night and wondered about the birth of the universe? And who has not been stimulated by the sight of the newly born baby to the marvel at the unseen events within the mother's uterus that have led to the birth of such a perfect creation?" These words were written by Professor Sir Graham (Mont) Liggins and opened up a Pandora's box of numerous questions, dilemmas, doubts, and controversies about human life and its beginning, offering everybody lifelong challenge to solve the mystery of life.

\section{DEFINITION OF LIFE}

The right answer to the question "How to define human life?" is complicated. Nowadays, dilemmas of human life from birth to death involve not just biology but also other sciences. Disciplines, such as philosophy, theology, psychology, sociology, law, and politics, evaluate this topic from different point of views. Combining all of them would result in a proper definition. ${ }^{1-40}$

Some authors think that life does not exist since no one has ever seen it. Szent-Gyorgy says that the noun "life" does not mean anything because there is no such thing as "life." Le Dantez thinks that the expression "to live" is too general and that it is better to say a dog "dogs" or a fish "fishes" than a dog or a fish lives.

When defining life, it should be considered not just life as it is today but as it might have been in its primordial form and as it will be in the future. All present forms of life look as something completely new. Life, then, is transferred and not conceived in each new generation. Moreover, the phenomenon of life has existed on Earth for approximately 3.5 billion years. Consequently, even though the genome of a new embryo is unique, the make-up of an embryo is not new. If life is observed through the cell, then every life (and human life) is considered as a continuum. Human cells and mankind have been existing on the Earth constantly from the appearance of the first man. However, if the definition applies to the single human being or present population, the statement "human life is a continuum" is not acceptable.

Life, in its true sense of the word, begins when the chemical matter gives rise, in a specific way, to an autonomous, self-regulating, and self-reproducing system. Life is linked with a living being, and it created its own 
system as an indivisible whole and forms its individuality. One of the most significant characteristics of living beings is reproduction. Reproduction is a way of creating new life by transferring forms of the old one into newly formed human being. Consequently, variability, individual development, and harmony characterize human beings. Individuality is the most fundamental characteristic of human being, consisting not only of the new life but also all human life forms through the evolution, characterized by phenotype, behavior, and the capability to recognize and adapt. Human embryo and fetus gradually develop these characteristics.

Although we should not forget that today's research is tomorrow's benefit, ${ }^{1}$ conclusions about human life should not be treated in a one-sided manner, i.e., from one perspective. This reality should be regarded in all its richness: The embryo gives biologists and geneticists substance for consideration, but since we are talking about the beginning of a human life, it requires philosophicalanthropological consideration, theology, and social sciences. To protect it, we have to include ethics and law. This approach makes us to conclude that it is necessary to reject reductionism as well as integrism and to find the "golden middle" in between these two methodologies. ${ }^{2}$

\section{SCIENTIFIC APPROACH}

Biology characterizes a human being by dynamics of the system and its self-control (homeostasis), excitability (response to stimuli of different nature and origins), selfreproducibility, the heredity of the characters, and the evolutive trend. ${ }^{2}$ For biologists, it is important to specify which form of life phenomena we are referring to: Cell, organism population, or species. The basic level of organization and the simplest form of life are the cell. Biologically speaking, human cellular life never stops - or if it did stop, the disappearance of the human species would result - and is passed on from one generation to another. Individual organismic life of a human is defined within its life cycle, which is temporary, i.e., it has a beginning and an end. It is clear that life is an extremely dynamic phenomenon, which could be described and explained through the careful study of life processes and interactions by interdisciplinary approach. It is known that in humans, spermatozoa and oocyte are the two essential cells involved in creating human life. It is clear that biologists are most qualified to render judgment on this matter. Being able to understand the beginning of human life and development of the embryo/fetus could provide a definitive resolution. However, having a possibility to visualize early human development virtually from conception, perinatologists should be those who, by study, training, practice, and research, are singularly qualified.
The science allows our data about physical development of the human being but does not provide information about its personality and personhood.

\section{HUMAN EMBRYOGENESIS}

Only proper understanding of the process of human embryogenesis enables scientifically answering the question when the life cycle of human individual starts. Thus, in the text to follow, the main steps of the human developmental process are going to be described in brief, primarily during the first 15 days after fertilization. A human being comes from two living cells - the oocyte and the spermatozoon - transmitting the torch of life to the next generation. The oocyte is a cell measuring approximately $120 \mu \mathrm{m}$ in diameter with thick membrane, known as the zona pellucida. The spermatozoon moves using the flagellum or tail, and the total length of the spermatozoon including the tail is $60 \mu \mathrm{m}$.

After syngamy, the zygote, as it moves down the fallopian tube toward the uterus, undergoes mitotic cell division. A series of mitotic divisions leads to the development of the preembryo. We call the newly divided cells blastomeres. From 1 to 3 days after syngamy, it is divided into two cells and then four cells. Blastomeres develop cellular aggregates of distinct, totipotent, undifferentiated cells that, during several early cell divisions, maintain the capacity to develop independently into normal preembryos. Since the blastocyst is in the process of attaching to the uterine wall, the cells increase in number and organize into two layers of cells. Implantation progresses as the outer cell layer of the blastocyst, the trophectoderm, invades the uterine wall and erodes blood vessels and glands. Having begun 5 or more days after fertilization with the attachment of the blastocyst to the endometrial lining of the uterus, implantation will complete when the blastocyst is fully embedded in the endometrium several days later. Even during these 5 to 6 days, modern medicine presents the possibility of making preimplantation genetic diagnosis.

However, at this time, the cells are not yet totally differentiated related to their determination to specific cells or organs of the embryo. The term "preembryo" includes the developmental stages from the 1st cell division of the zygote through the morula and the blastocyst. Approximately, by the 14th day after the process of fertilization ends, all cells, depending on their position, will have become parts of the placenta and membranes or the embryo. The "embryo" stage, therefore, begins approximately 16 days after the fertilization process began and continues until the end of 8 weeks after fertilization, when organogenesis is complete.

Preembryo is the structure that exists from the end of the fertilization process until the appearance of a single 
primitive streak. Until the completion of implantation, preembryo is capable of dividing into multiple entities, but does not contain enough genetic information to develop into an embryo: It lacks genetic material from maternal mitochondria and of maternal and parental genetic messages in the form of messenger ribonucleic acid or proteins. So, during the preembryonic period, it has not yet been determined with certainty that a biological individual will result or that it would be one or more (identical twins forming), so that, the assignment of full rights of a human person is inconsistent with biological reality.

The conclusion is that the preembryo requires the establishment of special rules in society: It cannot claim absolute protection based on the claims of personhood; although meriting respect, it does not have the same moral value that a human person has. Today, the widely accepted opinion is that until the 14th day from fertilization - or at least until implantation - the human embryo may not be considered, from the ontological point of view, as an individual.

Genetic uniqueness and singleness coincide only after implantation and restriction have been completed, which are about 3 weeks after fertilization. Until that period, the zygote and its sequelae are in a fluid process, are not a physical individual, and consequently cannot be a person. It is a well-known fact that high percentages of oocytes that have been penetrated never proceed on to the further development and that many oocytes that do are thwarted so early in their development that their presence is not even recognized. It is suggested that $30 \%$ of conceptions detected by positive reactions to human chorionic gonadotropin (hCG) tests abort spontaneously before these pregnancies are clinically verified. The newly conceived preembryo presents itself as a biologically defined reality. However, the status of the preembryo as an individual remains a great mystery.

In the present scientific scene, especially with the progress of ultrasound technologies, prenatal psychology and therapeutics have opened a window into the prenatal life of embryo and fetus confirming the evidence that the embryo/fetus is a true subject itself.

\section{PERSONALITY}

Defining personality proved to be very complex. There is still no clear definition of personality. One dictionary offers that this is "what constitutes an individual as distinct person," but does not define what the "what" is. Another dictionary asserts "the state of existing as a thinking intelligent being." This definition might lead to the inference that personality increases pro rata with intelligence or that some people may not have a personality at all if we followed Bertrand Russell's dictum that "most people would rather die than think and many, in fact, do!" Ken Stallworthy's Manual of Psychiatry is more helpful with the definition that "personality is the individual as a whole with everything about him which makes him different from other people" because we can certainly distinguish fetuses from each other and from other people. With the next sentence - "personality is determined by what is born in the individual in the first place and by everything which subsequently happens to him in the second" - we are really in the field., ${ }^{2,3}$

Led by the truism "No insignificant person was ever born," a human being should be valued from birth to natural death. But, as always in the modern world, truism is literally turned on its head when a person is selectively devalued, made insignificant on the basis, e.g., of skin color, religious belief, etc. Therefore, it is hard to establish proper values and exact definitions. This becomes true especially when prenatal life is considered. The above-stated truism opens an important question: "Is the person - unborn a person in the first place and, if so, is the person - unborn a 'significant' person?"2

Let us evaluate further present controversies. There is no doubt that the embryo and fetus in utero are human individuals prior to birth. The child who is born is the same developing human individual as it was in the mother's womb. Birth alone cannot present natural personhood or human individuality. This is strengthened by preterm deliveries of babies who are as truly human and almost as viable as those whose gestation goes to full term. All the known evidence supports the human fetus being a true ontological human individual and consequently a human person in fact if not in law. A human being cannot begin before the appropriate brain structures that are capable of sustaining awareness are not developed. The same is valid for a grossly malformed fetus. It would still be a human individual even if its human nature was not perfect or its functions quite normal. Nobody questions the humanity of a Down's syndrome fetus or child. A fetus or child with severe open spina bifida is not less of a human being. The same should be said for the live anencephalic fetus or infant with only brain stem functions. It is still a human individual even if it lacks a complete brain and usually survives birth by only a few hours or a day.

Human society created several standards in defining "person" or "human being" based on what is familiar and easily recognizable. ${ }^{2}$ For example, a human speaks, understands, and laughs. The absence of these characteristics (mutism, autism, and stoicism) does not disqualify. On the contrary, the conclusion is that the characteristics we have come to associate with being a person may not be applicable to each individual person. Therefore, it is necessary to establish criteria for definition of "person" in society and in time. Italian professors ${ }^{4}$ committed 
themselves to care for such embryos, giving the same dignity to every patient, and the human conditions to grow and develop, to educate others inside and outside the specialty, and to carry out research involving all the components of society.

\section{BIOETHICAL ASPECTS}

The idea of the embryo/fetus as a miniaturized infant or adult is true to the extent that the embryonic/fetal physiologist must be able to apply knowledge of every system obtained, yet quite untrue in failing to recognize the many ways in which life before birth differs fundamentally from life after birth. ${ }^{1}$ The newly conceived form presents itself as the biologically defined reality: It is an individual i.e., completely human in development, which autonomously, moment by moment without any discontinuity, actualizes its proper form in order to realize through intrinsic activity a design present in its own genome. ${ }^{4}$ The embryo as a patient is best understood as the subset of the concept of the fetus as the patient. These two concepts opened a whole set of questions regarding ethical problems. The embryo as the patient is indivisible from its mother. However, balance is needed in protection of the interests of the embryo/fetus and the mother. One prominent approach to understanding the concept of the embryo/fetus as a patient has involved attempts to show whether or not the embryo/fetus has independent moral status or personhood. Independent moral status for the fetus would mean that one or more of the characteristics possessed either in or of the embryo/fetus itself, and therefore independently of the pregnant woman or any other factor, generate, and therefore ground obligations to the embryo/fetus on the part of the pregnant woman and her physician.

A wide range of intrinsic characteristics has been considered for this role, for example, moment of conception, implantation, central nervous system development, quickening, and the moment of birth. Given the variability of proposed characteristics, there are many views about when the embryo/fetus does or does not acquire independent moral status. Some take the view that the embryo/fetus possesses independent moral status from the moment of conception or implantation. Others believe that the embryo/fetus acquires independent moral status in degrees, thus resulting in "graded" moral status. Still others hold, at least implicitly, that the embryo/fetus never has independent moral status so long as it is in utero. Being a patient does not oblige that one possesses independent moral status. Being a patient means that one can benefit from the application of the clinical skills of the physician. Put more precisely, a human being without independent moral status is properly regarded as a patient when the following conditions are met: That a human being is presented to the physician for the purpose of applying clinical interventions that are reliably expected to be efficacious; in that, they are reliably expected to result in a greater balance of goods over harms in the future of the human being in question. ${ }^{5}$ In other words, an individual is considered a patient when a physician has beneficence-based ethical obligations to that individual.

To clarify the concept of the embryo/fetus as the patient, beneficence-based obligation is necessary to be provided. Beneficence-based obligations to the fetus and embryo exist when the fetus can later achieve independent moral status. ${ }^{6}$ This leads to the conclusion that ethical significance of the unborn child is in direct link with the child to be born - the child it can become.

\section{LEGAL STATUS OF THE EMBRYO}

When discussing law, it should be always kept in mind that medicine is international, but law is not.

The status of the human embryo is not juridically defined and relies on the political, social, and religious influences in each country. It is not easy to answer the question when human life should be legally protected. Should it be at the time of conception, or at the time of implantation, or at the time of birth? In all countries, with the exception of Ireland and Liechtenstein, juridical considerations are based on the Roman law. Roman civil law states that the fetus has right when it is born or if it is born-nasciturus. Few countries agree with the definition of the beginning of human personality at the time of conception. The majority does not grant legal status to the human embryo in vitro (i.e., during the 14 days after fertilization). Thus, even in the absence of legal rights, there is no denying that the embryo constitutes the beginning of human life, a member of the human family. Therefore, whatever the attitude, every country has to investigate which practices are compatible with the respect of that dignity and the security of human genetic material.

\section{ARGUMENTS FOR BEGINNING OF HUMAN LIFE AND HUMAN PERSON AT FERTILIZATION}

The fundamental approaches of biomedical and social practice must begin with the understanding that the subject before birth is a person and that "personhood" is conferred by successful fertilization of the egg. To hide from this in silence or ignorance should be unacceptable to all, as stressed by Scarpelli. ${ }^{17}$

The view that human life begins when sperm and eggs fuse to give rise to a single-cell human zygote whose genetic individuality and uniqueness remain unchanged during normal development is widely supported. Because the zygote has the capacity to become an adult human 
individual, it is thought it must be one already. The same zygote arranges itself into an embryo, a fetus, a child, and an adult. By this account, the zygote is an actual human individual and not simple a potential one, in much the same way an infant is an actual human person with potential to develop to maturity and not just a potential person. As Scarpelli ${ }^{17}$ pointed out recently, outside the realm of religious dogma, there has been no one whose existence can be traced back to any entity other than the fertilized egg. The biological line of existence of each individual, without exception, begins precisely when fertilization of the egg is successful.

The process of fertilization actually begins with conditioning of the spermatozoon in the male and female reproductive tracts. Thereafter, fertilization involves not only the egg itself but also the various investments that surround the egg at the time it is released from the ovary follicle. Fertilization, therefore, is not an event, but a complex biochemical process requiring a minimum of 24 hours to complete syngamy, i.e., the formation of a diploid set of chromosomes. During this process, there is no commingling of maternal and paternal chromosomes within a single nuclear membrane (prezygote); after this process, the parental chromosomes material is commingled (zygote).

Among the many other activities of this new cell, most important is the recognition of the new genome, which represents the principal information center for the development of the new human being and for all its further activities. For the better understanding of the very nature of the zygote, two main features are to be at least mentioned here. The first feature is that the zygote exists and operates singly as a being, ontologically one, and with a precise identity. The second feature is that the zygote is essentially oriented and determined to a definite development. Both identity and orientation are due basically to the genetic information with which, it is endowed. That is why many do believe that this cell represents the exact point in time and space where a new human individual organism initiates its own life cycle. ${ }^{2}$

\section{ARGUMENTS AGAINST BEGINNING OF HUMAN LIFE AT FERTILIZATION}

Today, one largely accepted opinion is that until the 14th day from fertilization - or at least until implantation the human embryo, from an ontological point of view, may not be considered as an individual. There are at least five main reasons in favor of this opinion:

1. Before formation of embryonic disk, embryo is "a mass of cells genetically human," "a cluster of distinct individual cells," which are each "distinct ontological entities in simple contact with the others."
2. Until approximately the 14 th day after fertilization, all that happens is simply a preparation of the protective and nutritional systems required for the future needs of the embryo. Only when the entity called embryonic disk is formed can embryo develop into a fetus.

3. It is possible that monozygotic twin phenomena or chimeras occur. In fact, this seems to be the strongest reason why the embryo is denied the quality of individuality and proof that the zygote cannot be an ontological human being. In approximately one-third of the cases, the embryo divides at about the two-cell stage, and in the other two-thirds, the inner cell mass divides within the blastocyst from day 38 . Occasionally, the division takes place from day 8 to 12 , but usually it is not complete, thereby forming conjoined identical twins on two-headed individuals.

4. Coexistence of the embryo with its mother is a necessary condition for an embryo belonging to the human species, and this condition can be achieved only at implantation. ${ }^{8}$ However, there is evidence that development of human embryo in vitro can continue well beyond the stage of implantation and that mouse embryos implanted under the male renal capsule can reach the fetal stage. It is also discussed, or at least implied, that so many human embryos die before or after implantation that it would not be realistic to accept that the human individual begins before implantation. It is recognized that high percentages of oocytes that have been penetrated never proceed on to further development and that many oocytes that do are thwarted so early in their development that their presence is not even recognized. Up to $50 \%$ of ovulated eggs and zygotes recovered after operations were found so grossly abnormal that it would be very unlikely that they would result in viable pregnancies.

It is also suggested that $30 \%$ of conceptions detected by positive reactions to hCG tests abort spontaneously before these pregnancies are clinically verified. The scientific literature is not unanimous on the incidence of natural wastage prior to, and during, implantation in humans, varying from $15 \%$ to as much as $50 \%$. The vast majority of these losses are due to the chromosomal defects caused during gametogenesis and fertilization. Only after implantation and restriction have completed, which are about 3 weeks after fertilization, genetic uniqueness and singleness coincide. Until that period, the zygote and its sequelae are in a fluid process, are not a physical individual, and therefore cannot be a person.

5. The product of fertilization may be a tumor, a hydatidiform mole, or a chorioepithelioma. Though the mole is alive and of human origin, it is definitely not a human individual or human being. It does not have 
a true human nature from the start and has no natural potential to begin human development.

A teratoma is another clear instance of cells developing abnormally that result from the product of fertilization, but which could not be considered to be a true human individual with a human nature. It does not have the potential to develop into an entire fetus or infant. Clearly, the fetus with the teratoma would be a human individual, but not the attached teratoma itself. Obviously, not all the living cells that develop from the conceptus, the early embryo, or the fetus form an integral part of a developing human individual. $^{3}$

\section{DIFFERENT RELIGIOUS TEACHINGS AND HISTORICAL ASPECTS}

The Catholic Church's teachings are clearly described in the Introduction to Donum Vitae: "A human creature is to be respected and treated as a person from conception and therefore, from that same time his (her) rights as a person must be recognized, among which in the first place is the invaluable right to life of each innocent human creature."

In 1997, the 3rd Assembly of the Pontifical Academy for Life was held in Vatican City. It concluded that "at the fusion of two gametes, a new real human individual initiates its own existence, or life cycle, during which given all the necessary and sufficient conditions - it will autonomously realize all the potentialities with which he is intrinsically endowed." The embryo, therefore, from the time the gametes fuse, is a real human individual, not a potential human individual. It was even added that recent findings of human biological science recognize that in zygotes resulting from fertilization, the biological identity of a new human individual is already constituted.

In Western Europe and in North and South America, these opinions are mostly based on Judeo-Christian theology; in Arabian countries, in Africa, and in Asia, the influences of the Islamic and Buddhist religions prevail. Although their approach to the beginning of human life is impressively similar, each of these religions has different attitudes to the problem of embryo research, infertility, and its therapy. In fact, while the Jewish attitude toward infertility is expressed in the Talmud sayings and in the Bible (synthesized in the first commandment of God to Adam, "Be fruitful and multiply"), the Christian point of view establishes no absolute right to parenthood. According to the Islamic views, attempts to cure infertility are not only permissible, but also a duty. Buddhism has imposed strict ethics on priests, but it has relatively moderate attitudes toward lay people, so if medical treatment for infertility is available, people should make use of it.
For about 2000 years, the opinions of Aristotle, the great Greek philosopher and naturalist, on the beginning of the human being were commonly held. He argued that the male semen had a special power residing in it, pneuma, to transform the menstrual blood first into a living being with a vegetative soul after 7 days, and subsequently into one with a sensitive soul 40 days after contact with the male semen. Aquinas adopted Aristotle's theory, but specified that rational ensoulment took place through the creative act of God to transform the living creature into a human being once it had acquired a sensitive soul. The first conception took place over 7 days, while the second conception or complete formation of the living individual with a complete human nature lasted 40 days.

Hippocrates believed that the entrance of the soul into the male embryo occurred on the 30th day of intrauterine life. It entered into the female embryo on the 40th day. Actually, this idea was a considerable improvement on the scheme found in the Book of Leviticus, where it is suggested that the soul does not enter the female until 40 days after the conception. In short, the rational soul enables the matter to become a human being, an animated body, an embodied soul, a human person.

Harvey's experiments with deer in 1633 proved Aristotle's theory of human reproduction wrong, without finding a satisfactory explanation of human conception.

After modern scientists discovered the process of fertilization, most people took for granted that human beings, complete with a rational soul, began once fertilization had taken place.

It is clear that the answer to the question "When has the human being actually come to life?" could only be given by bringing together the cognition of different religions, philosophy, and various biological scientific disciplines. There is a very fine line between the competence of science and that of metaphysics, and it greatly depends on the individual's philosophical principles. Those two, more or less autonomous intellectual disciplines have very often tried dominating one another, or ignoring each other. It is only recently that the majority of scientists and some theologists have come to realize that the separate meanings of scientific and religious "truths" complement themselves, thus representing methodologically independent entities. Current science is not interested in what Nature is, but in the facts that could be started regarding it, thus trying to explain the term, rather than inventing it. The main difference between science and religion can be seen in the fact that scientific "truths," unlike religious postulates, can and must be experimentally verified, and the methods of scientific cognition can be easily explained and learnt. While religion favors irrationality, science prefers an entirely rational approach to the matters of 
importance. Intellectual cognition when scientifically expressed usually is in a form of mathematical formulas and presented quantitatively. On the contrary, religion tends to keep its truths in the form of metaphoric expressions, preferring qualitative presentation. Today, there is a tendency, on a higher level, to reopen the dialogue between science and religion, which was present at the very beginning of our culture. Religion had existed long before science came to life, but science is not to be thought of as a continuation of the religion. Each discipline should preserve its principles, its separate interpretations, and its own conclusions. In the end, both of them represent different components of the one and indivisible culture of mankind.

\section{VISUALIZATION OF EARLY HUMAN DEVELOPMENT}

Significant advances have been made in recent years in visualizing and analyzing the earliest human development. Most of them have been done by introduction of three-dimensional (3D) color Doppler sonography.

Many new parameters about early human development are now examined and studied by Doppler ultrasound. A considerable number of biochemical, morphological, and vascular changes occur within the follicle during the process of ovulation and luteinization, and most of them can be studied by transvaginal ultrasound with color Doppler and 3D facilities. If the oocyte is fertilized, the embryo is transported into the uterus where under favorable hormonal and environmental conditions, it will implant and develop into a new and unique individual. The introduction of transvaginal color Doppler improved the detection of blood vessels enabling detailed examination of small vessels, such as arteries supplying preovulatory follicle, corpus luteum, and endometrium. ${ }^{9}$

Perifollicular vascularization can help in identification of follicles containing high-quality oocytes, with a high probability of recuperating, fertilizing, cleaving, and implanting, while 3D ultrasound enables accurate morphological inspection and detection of cumulus oophorus. Follicles without visualization of the cumulus by multiplanar imaging are not likely to contain fertilizable oocytes. This information is especially useful in patients undergoing ovulation induction.

Following ovulation, the corpus luteum is formed as a result of many structural, functional, and vascular changes in the former follicular wall. Color Doppler studies of the luteal blood flow velocities enable evaluation of the corpus luteum function in the second phase of menstrual cycle and early pregnancy. When the placenta takes over the role of production of progesterone, the corpus luteum starts to regress. After ovulation, there is a short period during which the endometrial receptivity is maximal. During these few days, a blastocyst can attach to the endometrium and provoke increased vascular permeability and vasodilatation at the implantation site. Trophoblast-produced proteolytic enzymes cause the penetration of the uterine mucosa and erode adjacent maternal capillaries. This results in the formation of the intercommunicating lacunar network - the intervillous space of the placenta. A small intradecidual gestational sac can be visualized by transvaginal sonography between 32 and 34 days.

The secondary yolk sac is the earliest extraembryonic structure normally seen within the gestational sac in the beginning of the 5 th gestational week. The yolk sac volume was found to increase from 5 to 10 weeks' gestation. When the yolk sac reaches its maximum volume at around 10 weeks' gestation, it has already started to degenerate, which can be indirectly proved by a considerable reduction in visualization rates of the yolk sac vascularity. ${ }^{10}$ Therefore, a combination of functional and volumetric studies by 3D power Doppler helps to identify some of the most important moments in early human development.

The embryonic heart begins beating on about days 22 to 23 , accepting blood components from the yolk sac and pushing blood into the circulation. The embryonic blood begins circulating at the end of the 4 th week of development.

The start of the embryo-chorionic circulation changes the source of nourishment to all intraembryonic tissues. The survival and further development of the embryo become dependent on the circulation of embryonic/ fetal blood. If the embryo-chorionic circulation does not develop, or fails, the conceptus is aborted. The embryo cannot survive without the chorion (placenta), and the chorion will not survive without the embryo. Avascular degenerated chorionic villi constitute the hydatidiform mole. Within the embryo, there are three different blood circulatory systems ${ }^{7}$ :

1. Vitelline circulation (from yolk sac to embryo)

2. Intraembryonic circulation

3. Two umbilical arteries (from embryo to placenta fetoplacental circulation).

It is possible to visualize and assess them virtually from conception.

At 5 weeks from the maternal side of placenta, it is possible to obtain simultaneously 3D imaging of the developing intervillous circulation during the 1st trimester of pregnancy. Three-dimensional power Doppler reveals intensive vascular activity surrounding the chorionic shell starting from the first sonographic evidence of the developing pregnancy during the 5 th week of gestation. 
At 7 weeks, 3D power Doppler images depict aortic and umbilical blood flow. Initial branches of umbilical vessels are visible at the placental umbilical insertion.

During the 8th and 9th weeks of pregnancy, the developing intestine is being herniated into the proximal umbilical cord. At 9 to 10 weeks, herniation of the midgut is present. The arms with elbow and legs with knee are clearly visible, while feet can be seen approaching the midline.

At 11 weeks, 3D power Doppler imaging allows visualization of the entire fetal and placental circulation.

During the 11th and 12th weeks of pregnancy, development of the head and neck continues. Facial details as nose, orbits, maxilla, and mandibles are often visible. Herniated midgut returns into the abdominal cavity.

\section{NEW POSSIBILITIES FOR STUDYING EMBRYONIC MOVEMENTS AND BEHAVIOR}

The latest development of 3D and four-dimensional (4D) sonography enables precise study of embryonic and fetal activity and behavior. With 4D ultrasound, movements of head, body, and all four limbs and extremities can be seen simultaneously in three dimensions. Thus, the earliest phases of the human anatomical and motor development can be visualized and studied simultaneously. It is clear that neurologic development - early fetal motor activity and behavior - needs to be reevaluated by this new technique. During the last years, our group studied the development of the complexity of spontaneous embryonic and fetal movements. With advancing of the gestational age, the movements become more and more complex. The increase in the number of axodendritic and axosomatic synapses between 8 and 10 weeks, and again between 12 and 15 weeks, correlates with the periods of fetal movement differentiation and with the onset of general movements and complex activity patterns, such as swallowing, stretching, and yawning, seen easily by $4 \mathrm{D}$ technique. By 7 to 8 weeks of pregnancy, gross body movements appear. They consist of changing the position of head toward the body. By 9 to 10 weeks of pregnancy, limb movements appear. They consist of changing of position of extremities toward the body without the extension or flexion in elbow and knee. By 10 to 12 weeks of pregnancy, complex limb movements appear. They consist of changes in position of limb segments toward each other, such as extension and flexion in elbow and knee.

By 12 to 15 weeks of pregnancy, swallowing, stretching, and yawning activities appear. In addition to these activities, it is now feasible to study by $4 \mathrm{D}$ ultrasound a full range of facial expression including smiling, crying, and eyelid movement. It is hoped that new $4 \mathrm{D}$ techniques will help us better understand both somatic and motoric development of the early embryo. It will also enable reliable study of fetal and even parental behavior. ${ }^{11}$ While writing this review, new technique 3D HD silhouette has been introduced into clinical practice. This might revolutionize visualization of the early human development. ${ }^{12-14}$

\section{CONCLUSION}

Self awareness is one of the fundamental, possibly the most fundamental, characteristic[s] of the human species . This characteristic is an evaluatory novelty; the biological species form which mankind has descended had only rudiments of self-awareness has, however, brought in its train somber companions - fear, anxiety, and death awareness." -T Dobzhansky

The question of when a human life begins and how to define it could be answered only through the innerconnecting pathways of history, philosophy, and medical science. It has not been easy to determine where to draw the fine line between the competence of science and metaphysics in this delicate philosophical field. To a large extent, the drawing of this line depends on one's fundamental philosophical outlook.

\section{REFERENCES}

1. Serra A, Colombo R. Identity and status of the human embryo: the contribution of biology. In: de Dios Vial Correa J, Sgreccia E, editors. Identity and statute of human embryo. Vatican: Libreria Editrice Vaticana; 1998. p. 128.

2. Liggins G (Mont). Foreword. In: Nathanielsz PW, editor. Life before birth and the time to be born. Ithaca (NY): Promethean Press; 1992.

3. Kurjak A. When does human life begin? Encyclopedia Moderna 1992;383-390.

4. The Embryo as a Patient. Declaration of Professors from Five Faculties of Medicine and Surgery of the universities of Rome, organizers of the Conference. La Sapienza University Press; 2004.

5. Chervenak FA, McCullough LB, Kurjak A. Ethical implications of the embryo as a patient. In: Kurjak A, Chervenak FA, Carrera JM, editors. The embryo as a patient. New York/ London: Parthenon Publishing Group; 2001. p. 226-230.

6. McCullogh LB, Chervenak FA. Ethics in obstetrics and gynecology. New York (NY): Oxford University Press; 1994.

7. Jirasek JE. An Atlas of the human embryo and fetus. New York/London: Parthenon Publishing; 2001.

8. Curran CE. Abortion: contemporary debate in philosophical and religious ethics. In: Reich WT, editors. Encyclopedia of bioethics. New York (NY): Macmillan; 1978. p. 17-26.

9. McLaren A. Prelude to embryogenesis, in the Ciba Foundation, Human Embryo Research, Yes or No? London, New York: Tavistock; 1986. p. 5-23.

10. Ford NM. When did I begin? Conception of the human individual in history, philosophy and science. Cambridge (MA): Cambridge University Press; 1991. p. 137-146.

11. Campbell S. 4D, or not 4D: that is the question. Ultrasound Obstet Gynecol 2002 Jan;19(1):1-4.

12. Pooh RK, Kurjak A. Novel application of three-dimensional HD live imaging in prenatal diagnosis from the first trimester J Perinat Med 2015 Mar;43(2):147-158. 
13. Kurjak A, Pooh RK. Early abnormal pregnancy (before 11 weeks). In: Pooh RK, Kurjak A, editors. Donald School Atlas of advanced ultrasound in obstetrics and gynecology. New Delhi: Jaypee Brothers Medical Publishers (P) Ltd; 2016. p. 65-89.

14. Kurjak A, Carrera JM, McCullough LB, Chervenak FA. Scientific and religious controversies about the beginning of human life: the relevance of the ethical concept of the fetus as a patient. J Perinat Med 2007;35(5):376-383.

15. Godfrey J. The Pope and the ontogeny of persons (commentary). Nature 1995 Jan 12;373(6510):100.

16. Gilbert SF. Developmental biology. Sunderland (MA): Sinauer Associates; 1991. p. 3.

17. Scarpelli EM. Personhood: a biological phenomenon. J Perinat Med 2001 29(5):417-426.

18. ACOG Committee Opinion: Committee on Ethics. Preembryo research: history scientific background, and ethical considerations. Int J Gynecol Obstet 1994 Jun;45(3):291-301.

19. Bush GW. Presidential Inaugural Address. Washington, DC; 2001 Jan 20.

20. Engelhardt HT Jr. The foundation of bioethics. New York (NY): Oxford University Press; 1986.

21. Dunstan GR. The moral status of the human embryo: a tradition recalled. J Med Ethics 1984 Mar;10(1):38-44.

22. Ruddick W, Wilcox W. Operating on the fetus. Hastings Cen Rep 1982 Oct;12(5):10-14.

23. Pierre F, Soutoul JH. Medical and legal complications. J Gynecol Obstet Biol Reprod (Paris) 1994;23(5):516-519.

24. Abel F. Nascita e morte dell'uomo: prospettive della biologia e della medicina. In: Biolo S, editor. Nascita e morte dell'uomo. Problemi filosofici e scientifici della bioetica, Genova: Marieti; 1993. p. 37-53.

25. Johnson M. Delayed hominization: reflections on some recent catholic claims for delayed hominization. Theol Stud 1995 Dec;56:743-763.

26. Congregation for the Doctrine of the Faith, Instruction on respect for human life in its origin and on the dignity of procreation "Donum Vitae" (February 12, 1987). Acta Apostolicae Sedis 1988;80:70-102.

27. Beazley JM. Fetal assessment from conception to birth. In: Kurjak A, editor. Recent advances in ultrasound diagnosis 2. Amsterdam: Excerpta Medica; 1980. p. 128.
28. Kurjak A. Kada pocinje zivot. In: Kurjak A, editor. Ocekujuci novorodjence. Zagreb: Naprijed; 1987. p. 18-28.

29. Kupesic $S$. The first three weeks assessed by transvaginal color Doppler. J Perinat Med 1996;24(4):310-317.

30. Kupesic S, Kurjak A, Ivancić-Kosuta M. Volume and vascularity of the yolk sac. J Perinat Med 1999;27(2):91-96.

31. Kurjak A, Predanic M, Kupesic S. Transvaginal color Doppler study of middle cerebral artery blood flow in early normal and abnormal pregnancy. Ultrasound Obstet Gynecol 1992 Nov 1;2(6):424-428.

32. Kurjak A, Kupesic S. Doppler assessment of the intervillous blood flow in normal and abnormal early pregnancy. Obstet Gynecol 1997 Feb;89(2):252-256.

33. Kurjak A, Kupesic S, Hafner T. Intervillous blood flow in normal and abnormal early pregnancy. Croatian Med J 1998; 39(1):10.

34. Kurjak A, Kupesic S. Three-dimensional transvaginal ultrasound improves measurement of nuchal translucency. J Perinat Med 1999;27(2):97-102.

35. Kurjak A, Kupesic S, Banovic I, Hafner T, Kos M. The study of morphology and circulation of early embryo by threedimensional ultrasound and power Doppler. J Perinat Med 1999;27(3):145-157.

36. Lee A. Four-dimensional ultrasound in prenatal diagnosis: leading edge in imaging technology. Ultrasound Rev Obstet Gynecol 2001;1(2):144-148.

37. de Vries JI, Visser GH, Prechtl HF. The emergence of fetal behaviour. I. Qualitative aspects. Early Hum Dev 1982 Dec;7(4):301-322.

38. de Vries JI, Visser GH, Prechtl HF. The emergence of fetal behaviour. II. Qualitative aspects. Early Hum Dev 1985 Nov;12(2):99-120.

39. Kurjak A, Vecek N, Hafner T, Bozek T, Funduk-Kurjak B, Ujevic B. Prenatal diagnosis: what does four-dimensional ultrasound add? J Perinat Med 2002;30(1):57-62.

40. Okado N, Kojima T. Ontogenity of the central nervous system: neurogenesis, fibre connection, synaptogenesis and myelination in the spinal cord. In: Prechtl HFR, editor. Continuity of neural functions from prenatal to postnatal life. Oxford: Blackwell Scientific; 1984. p. 46-64. 